\title{
Testicular structure and spermatogenesis of short mackerel, Rastrelliger brachysoma (Bleeker, 1851) in Upper Gulf of Thailand
}

\author{
Sinlapachai Senarat ${ }^{\mathrm{a}}$, Wannee Jiraungkoorskul ${ }^{\mathrm{b}}$, Jes Kettratad ${ }^{\mathrm{a}^{*}}$ \\ ${ }^{a}$ Department of Marine Science, Faculty of Science, Chulalongkorn University, Bangkok 10330, Thailand \\ ${ }^{b}$ Department of Pathobiology, Faculty of Science, Mabidol University, Bangkok 10400, Thailand
}

Accepted 28th October 2018

\begin{abstract}
Testicular structure and spermatogenesis of short mackerel, Rastrelliger brachysoma (Bleeker, 1851) (Teleostei: Scombridae) was first investigated. The testicular parenchyma was a lobular organ, which was classified as an unrestricted spermatogonial type. The classification of spermatogenetic stage could be classified into six stages based on the pattern of chromatin condensation and other characterizations at the light microscopic level. These six stages included the primary and secondary spermatogonium, primary and secondary spermatocyte, spermatid and spermatozoon. The spermatogenesis could also be classified into another four stages based on the nuclear and cytoplasmic characterizations at the ultrastructural level. Spermatogonium was the early germ cell. It underwent a series of mitotic division to reach the primary spermatocyte. Secondary spermatocyte was shown as the heterochromatin surrounding the nuclear membrane, which was rarely seen within seminiferous lobules. Stages during the spermatids differentiation comprised of the early, intermediate and late stages which are under the degree/change of chromatin condensation. Finally, the spermatozoon was revealed as the aquasperm primitive type. It was composed of an oval head without an acrosome, a short mid-piece consisting of two basal bodies (proximal and distal centrioles) and a long flagella tail without lateral fins. The axonemes of classical form with $9+2$ microtubules were presented in the flagellum.
\end{abstract}

Keywords: histology, Rastrelliger brachysoma, testis, Thailand

\section{INTRODUCTION}

Investigations in the testicular structure and spermatogenesis under light microscopic level, have been observed in several orders of teleost i.e., perciform, cypriniform, atheriniform and beloniform (Parenti and Grier, 2004; Dietrich and Krieger, 2009). Similarly, ultrastructural studies of the spermatogenic stages have also been investigated in teleost fish in Families: Anguillidae (Todd, 1976), Mugilidae (Brusle, 1981), Poeciliidae (Billard, 1984), Sparidae (Gwo et al., 1993), Characidae (Romagosa et al., 1999), Scombridae (Abascal et al., 2002), Synbranchidae (Lo Nostro et al., 2003) and Gobiidae (Chung,
2008). The sperm morphology was particularly investigated because it varied in its shape when compared to other vertebrate groups (Mattei, 1991; Jamieson and Leung, 2011). The interest in sperm morphology involved many aspects in fish biology such as reproductive biology, physiology, phylogenetic analysis and breeding (Jamieson and Leung, 1991; Mattei, 1991). Similarly in previous observation, the spermatozoa morphology in teleost fish have been used as a powerful tool in taxonomic and phylogenetic classification (Jamieson and Leung, 1991; Mattei, 1991). Not only a useful tool for the systematical analysis, but

* Author for correspondence: Dr. Jes Kettratad, Department of Marine Science, Faculty of Science, Chulalongkorn University, 10330 Bangkok, Thailand. Email -Jes.K@chula.ac.th 
also for the diversity of habitats and reproductive modes of the fishes. Surprisingly, spermatozoa morphology can be mainly classified into two types. A simple first type is the aquasperm spermatozoon, characterized by a round head with a short neck region (mid-piece), and few mitochondrias, whereas in the second type, the introsperm spermatozoon has the elongated head and other derived features including absence of the mid-piece and nuclear rotation (Jamieson and Grier, 1993; Jamieson, 2011; Mattei, 1991). Differences between these two types reflect the mode of fertilization in fishes (Jamieson and Grier, 1993; Jamieson, 2011). Among fishes, several scombrids such as Scomberomorus tritor (Mattei, 1991), Thunnus thynnus and Eutbynnus alletteratus (Abascal et al., 2002), Scomber australasicus (Hara and Okiyama, 1998), S. japonicas (Mattei, 1991; Hara and Okiyama, 1998) and Cybium tritor (Mattei, 1991) have especially observed due to their economical important value and investigated in male germ cells based on fine structure.

Unfortunately, no information has been done on the structure using light and electron microscopes of the spermatogenesis in the short mackerel Rastrelliger brachysoma. It is considered as the only marine species that is successfully managed in Thailand. However, due to recent reducing in sign of age of maturity, the Thai government is operating an aquaculture program for it. Therefore, it is the best candidate for further research as it is the promising prospect for aquaculture in Thailand. Hence, in this study, the testicular structure and spermatogenic stages of the $R$. brachysoma living in the Upper Gulf of Thailand were clarified using light and transmission electron microscopes.

\section{MATERIALS AND METHODS}

Animals and sampling. Adult R. brachysoma (15 to $18 \mathrm{~cm}$ standard length) were used in this study. Fish were collected by bamboo strake trap from Samut Songkram Province on the Upper Gulf of Thailand (13'16'18.4'N, 10002'13.4'E), during non-breeding season (October to December 2013, $\mathrm{n}=20$ ) and breeding season (January to February 2014, $\mathrm{n}=20$ ). These seasons were classified by the testicular development from our previous reports (Senarat et al., 2016; Senarat et al., unpublished data). All fish were euthanized by rapid cooling shock (Wilson et al., 2009). The experimental protocol was approved by the Animal Care and Use Committee of Faculty of Science in accordance with the guide for the care and use of laboratory animal prepared by Chulalongkorn University (Protocol Review No. 1423003).

Light microscopic observation. The testis tissues were immediately fixed in Davidson's fixative for 48 hours at room temperature and processed using standard histological. The testicular paraffin block was cut at $5 \mu \mathrm{m}$ thickness and stained with Harris' hematoxylin and eosin (H\&E) (Bancroft and Gamble, 2002). For histochemical technique, the basement membrane, reticular fiber, protein, carbohydrate and lipid contents of testis tissue were specific stained with Masson's trichrome (MT), periodic acid-schiff (PAS), alcian blue pH 2.5 (AB), germ positive (GP) and reticulin (RT) staining methods (modified from Puchtler and Waldrop, 1978; Vidal, 1988; Bancroft and Gamble, 2002). Additionally, frozen tissues were cut at $10 \mu \mathrm{m}$ thickness by freezing microtome and stained with oil red O (ORO) (modified from Culling, 1963).

Ultrastructural observation. Small pieces of testicular tissue (approximately $1 \mathrm{~mm}^{3}$ in size) were cut and rapidly prefixed in $2.5 \%$ glutaraldehyde (phosphate buffer $\mathrm{pH} 7.3$ ) for 24 hours at $4^{\circ} \mathrm{C}$ and postfixed in $1 \%$ osmium tetroxide. Testicular tissues were dehydrated in serial graded ethanol throughout embedding in epoxy resin (Epon 812). The semithin tissues were cut at $500 \mathrm{~nm}$ thickness, then stained with toluidine blue. Ultrathin sections were cut at 90 $\mathrm{nm}$ thickness, then stained with uranyl acetate and lead citrate. The sections were observed with a JEM-2100 (200kV) transmission electron microscope (TEM, JEOL, Japan).

\section{RESULTS}

Histology of testicular tissue. Asymmetrical macroanatomy of $\mathrm{R}$. brachysoma testes had paired organs and heart shape in cross section (Figures 
1A, 1B). They are situated in the dorsal part of the abdominal cavity, under the kidney. The cross sections revealed that the parenchyma of the testicular tissue was the anastomosing lobular type, which was surrounded by tunica albuginea. Its tunica albuginea was covered by mesothelium similar to the ovary (Figure 1A). The projection of tunica albuginea extended into the testicular parenchyma, forming lobules in the dorsal region, which was divided into two compartments (Figures 1A, 1D): (i) the interstitial compartment which contained the blood/lymphatic vessels, perilobular myoid cells and steroidogenic Leydig cells (Figures 1R, 1S). Perilobular myoid cells were elongated in shape. It was also showed the weakly acidophilic cells with surrounding the lobular. Steroidogenic Leydig cells had a large polygonal shape and were usually represented as small groups near blood capillaries in the interstitial compartment. Their nuclei were basophilic containing one nucleolus. (ii) The germinal compartment contained the numerous seminiferous lobules. The testis of $\mathrm{R}$ brachysoma was classified as unrestricted spermatogonial type because the spermatogonia occurred and were distributed along the entire length of the germinal compartment of the lobules (Figure 1E). Each seminiferous lobule composed of spermatogenic and somatic sertoli cells. The somatic sertoli cells had triangular nuclei with large, prominent nucleoli and slightly acidophilic cytoplasm. They were usually presented in low numbers and located adjacent to lobular septa. Each stage of spermatogenesis was synchronously developed, called spermatocyst.

Based on the structural features, such as cell size, shape, nuclear characteristics, chromatin condensation, amount of cytoplasm and staining properties, the spermatogenic process of $R$. brachysoma can be classified as follows:

Primary spermatogonium was the largest among the spermatogenic cells with diameter about 10-12 $\mu \mathrm{m}$. It was generally located as single cell near the seminiferous epithelial compartment. The center of the oval nucleus contained a very prominent single nucleolus with weakly basophilic nucleoplasm. The granular cytoplasm contained moderate amounts (Figure 1F).

Secondary spermatogonium derived from the primary spermatogonium by mitosis division. This stage was similar in character to the previous stage, but the nucleus had stronger basophilia than the primary spermatogonium due to the increase of heterochromatin condensation along the nuclear membrane. Each group (generally more than 4 cells) with $12-15 \mu \mathrm{m}$ in diameter was commonly found in cysts, called spermatocysts (Figures 1C, 1G).

Primary spermatocyte was formed when the secondary spermatogonia enters meiosis. Its size $(7-8 \mu \mathrm{m})$ was smaller than secondary spermatogonia and still occurred inside spermatocyst. The spherical or oval nucleus of secondary spermatocyte had a granule and stained as a basophilic cell with no prominent nucleolus. It exhibited a moderate amount of distinct acidophilic cytoplasm (Figure $1 \mathrm{H}$ ).

Secondary spermatocyte, developed from primary spermatocyte under the first meiotic division. It was relatively smaller in size, about 6 $7 \mu \mathrm{m}$ than that of primary spermatocytes. It contributed to the largest spermatocyst (35-40 $\mu \mathrm{m})$. The distinguishing feature of this stage was a change in shape and color of the nucleus; round nucleus increasingly condensed near the nuclear membrane without nucleolus $(5 \mu \mathrm{m})$ as basophilic chromatin, which did not contain. The basophilic staining of the second spermatocyte decreased as it depended (Figure 1I). However, it was rarely observed throughout the testis.

Spermatid derived from secondary spermatocyte after the second meiotic division. It was still contained inside spermatocyst. The oval nucleus was small with intensive basophilic. Rims of eosinophilic cytoplasm were shown, due to loss of its cytoplasm during spermiogenesis (Figures 1C, 1J).

Spermatozoon was the smallest spermatogenic cell. It was found in the lumen because of the spermatocyst capsule breaking out and then being released into vasa defferentia. It can be morphologically distinguished into 2 regions: head and tail. The ovoid head of the spermatozoon was responsible for its chromatins becoming completely condensed and was represented as strongly basophilic. The tail was strongly acidophilic with rarely apparent uniflagella in histological sections (Figures 1C, $1 \mathrm{~K})$. The spermatozoa within lumen which were released during spermiation into the ventral region were called the anastomosing zone before 
opening and continued with the vasa efferent, respectively.

\section{Histochemistry of testicular tissue}

Protein and carbohydrate. Histochemistry of the testicular tissue detected by $\mathrm{AB}$ (Figures 2A, 2B) as slightly positive as well as MT (Figures 2E,
2F) and PAS (Figures 2G, 2H) had strong positives for tunica albuginea and interstitial connective tissue, while spermatogonia and primary spermatocytes were slightly positive with PAS reaction. Both Leydig cells and somatic sertoli cells were moderately stained with the same reaction.

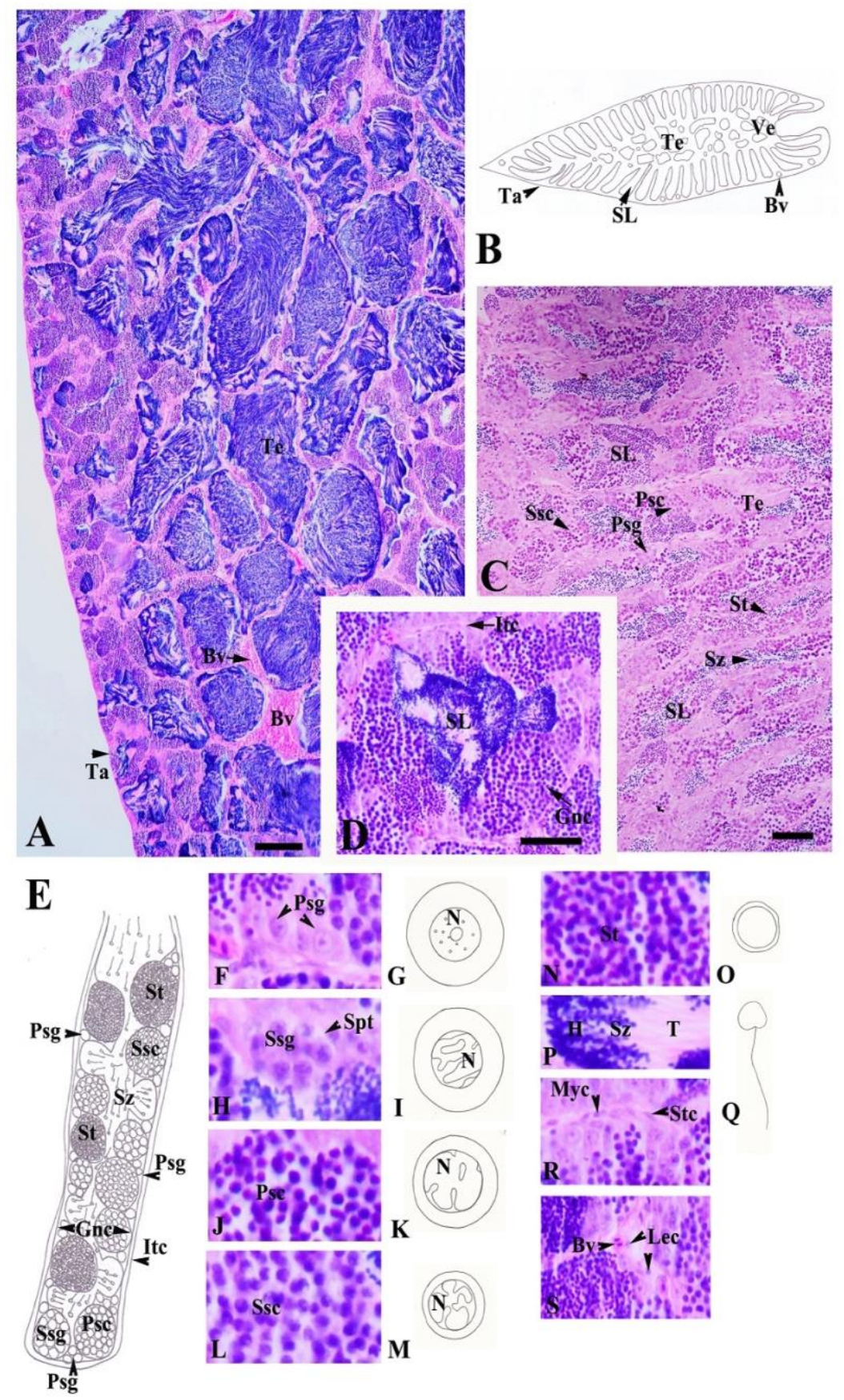

Figure 1. Light photomicrograph and schematic summary of testicular structure (A-E) and spermatogenesis (F-S). Note: blood vessel $(\mathrm{Bv})$, germinal compartment $(\mathrm{Gnc})$, head of spermatozoa $(\mathrm{H})$, interstitial compartment (Itc), Leydig cells (Lec), myoid cells (Myc), nucleus (N), primary spermatocyte (Psc), primary spermatogonia (Psg), seminiferous lobule (SL), spermatocyst (Spt), secondary spermatocyte (Ssc), secondary spermatogonia (Ssg), spermatids (St), sertoli cell (Stc), spermatozoa ( $\mathrm{Sz}$ ), tail of spermatozoa $(\mathrm{T})$, tunica albuginea $(\mathrm{Ta})$, testis $(\mathrm{Te})$, vasa efferentia $(\mathrm{Ve})$. Scale bar A, C, D = $100 \mu \mathrm{m}$. 

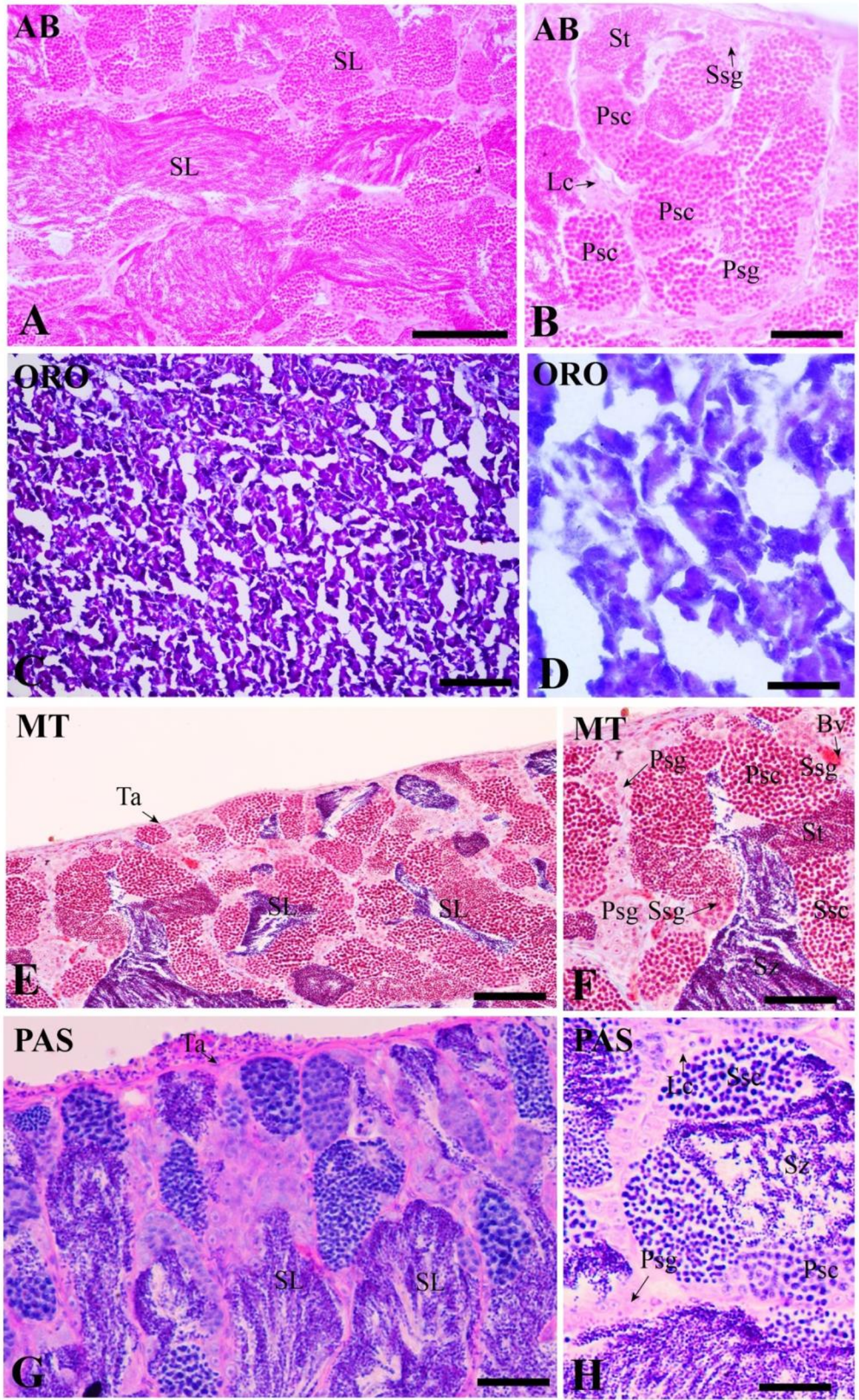

Figure 2. Light photomicrograph of testicular structure and spermatogenesis. (A-B) based on alcian blue pH 2.5 (AB), (C-D) based on oil red O (ORO), (E-I) based on Masson's trichrome (MT), and (H-J) based on periodic acid -schiff (PAS). Note: blood vessel (Bv), Leydig cell (Lc), primary spermatocyte (Psc), primary spermatogonia (Psg), seminiferous lobule (SL), secondary spermatocyte (Ssc), secondary spermatogonia (Ssg), spermatids (St), spermatozoa (Sz), tunica albuginea (Ta). Scale bar A, D, E, F, G, H $=100 \mu \mathrm{m} ; \mathrm{B}, \mathrm{C}, \mathrm{I}, \mathrm{J}=50 \mu \mathrm{m}$. 
Lipid. Overall testicular tissues were unstained with ORO, indicating the absence of lipids (Figures 6C, 6D).

Fiber composition. Reticulin reaction from longitudinal section revealed that the several blind ends of the lobule testis were established and protruded by tunica albuginea. Moreover, cross sections from the testis parenchyma also showed similar pattern. Basement membrane was obviously observed between germinal and interstitial compartments, respectively (Figures $3 \mathrm{~A}, 3 \mathrm{~B})$.

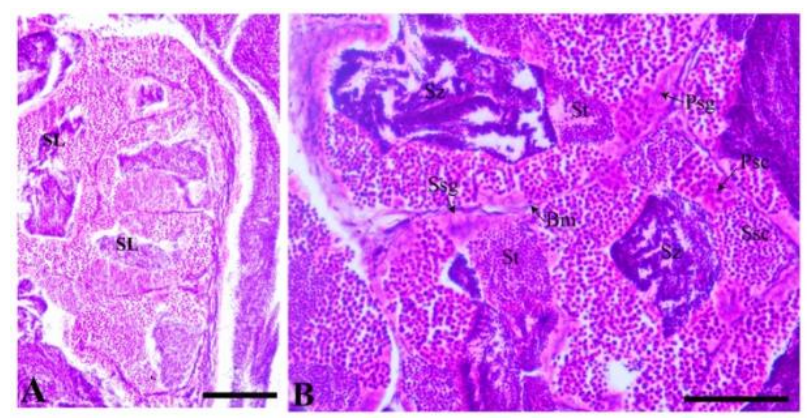

Figure 3. Light photomicrograph of testicular structure and spermatogenesis (A-B). Note: basement membrane $(\mathrm{Bm})$, primary spermatocyte (Psc), primary spermatogonia (Psg), seminiferous lobule (SL), secondary spermatogonia (Ssg), spermatids (St), spermatozoa (Sz). Scale bar A, B $=50 \mu \mathrm{m}$.

Ultrastructure of testicular tissue. Based on semithin section, normal testis of the adult $R$. brachysoma showed that the lobular lumen in germinal compartment contained various stages of spermatogenic cells during the reproductive season. Ultrastructure evidences e.g., cytoplasmic morphology and chromatin condensation of the nucleus were observed with TEM. Spermatogenesis in this species could be classified into 4 successive stages as follows:

Spermatogonium (approximately 10-12 $\mu \mathrm{m}$ ) was the largest male germ cells and occurred in small groups at the periphery of the seminiferous lobule (Figure 4A). TEM revealed that the spermatogonium was either slightly spherical or oval in shape. Its nucleus was large and prominent oval in shape, which was occupied by the presence of fine granular chromatin throughout the nucleoplasm. At this stage, a few cytoplasmic organelles such as several globular mitochondria were present (Figure 4B).

Primary spermatocyte originated mitotically from the spermatogonium. During the beginning of meiotic prophase, it was smaller than spermatogonia with approximately $8-9 \mu \mathrm{m}$ (Figure 4C). Under TEM, the nucleus of primary spermatocyte was the central oval-shape and the nucleolus was not visible. At this stage, the nucleus also contained densely packed chromatin as a heterochromatic nucleus (compared to spermatogonia). During pachytene stage under the meiotic division $\mathrm{I}$, there was an increasing condensation of heterochromatin among several synaptonemal complexes within the nucleus. The cytoplasm contained the endoplasmic reticulum, the electron dense particles, nuage and several mitochondria that became irregular in shape and electron dense matrix (Figures 4D, 4E). Intercellular bridge was observed at this stage.

Secondary spermatocyte was produced from the first mitotic division of primary spermatocytes. They could be identified at the structural level as having larger cysts when compared to the previous stages, but they were rarely seen with seminiferous lobules. A characteristic of the cell and nucleus were reduction in sizes $(6-7 \mu \mathrm{m})$ (Figure $4 \mathrm{~F}$ ). Ultrastructurally, the identifying characteristic of spherical nucleus was the appearance of the heterochromatin pattern around the nuclear membrane. The cytoplasm was reduced and still contained a few organelles. Intercellular bridge also frequently connected adjacent secondary spermatocytes (Figure 4F). This stage gave rise to spermatids under meiotic division II.

Spermatid was seen under chromatin condensation and cytoplasmic organelles changes during spermatid differentiation, called as spermiogenesis (Lahnsteiner and Patzner, 1990; Gwo et al., 1993). It could be classified into three morphological stages based on the modified criterion used in other families (Lahnsteiner and Patzner, 1990; Manni and Rasotto, 1997; QuagioGrassiotto and Oliveira, 2008). The early spermatid of spermiogenesis (approximately 4.0$4.5 \mu \mathrm{m})$ had a large and round nucleus shape (Figure 5A). Under TEM, remodelling of the chromatin condensation appeared, resulting in a granular-chromatin mass (Figure 5B). At this time, cytoplasmic organelles, such as spherical- 
mitochondria and centriole initially accumulated at the posterior regions (data not shown). The intermediate spermatid showed that the chromatin condensation of nucleus transformed into a more compact form, when compared with the previous stage. Also at this stage, the sphereshaped mitochondria was located near the posterior region of the nucleus (Figures 5C, 5D). The late spermatid, the proximal centriole was located within the nuclear fossa. Their flagellum axoneme which was arranged by mitochondria was located in the mid-piece. They were also separated from the flagellum by the cytoplasmic canal (Figures 5E, 5F). The chromatin completely condensed throughout the nucleus due to increase of dense and thick chromatin granules. The cytoplasm started to degenerate. The residual bodies in a various sizes and shapes were also found in the cytoplasm (Figure 5G).

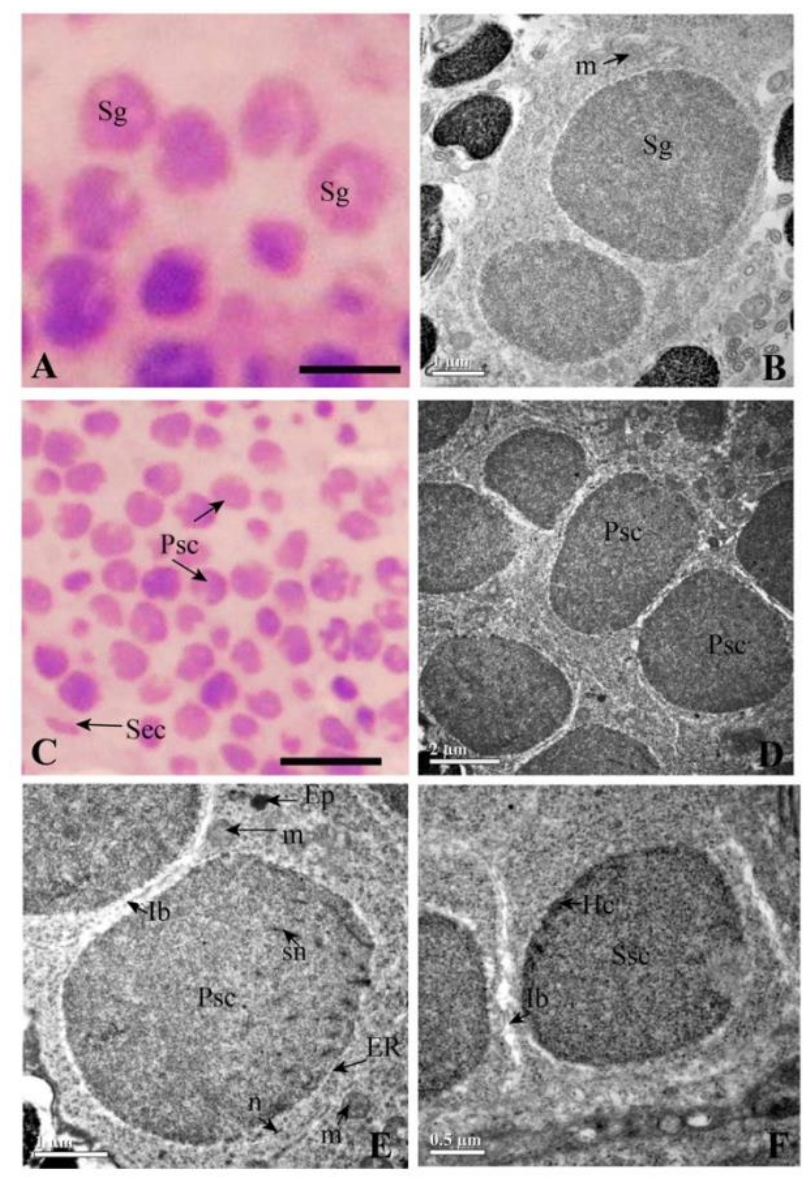

Figure 4. Photomicrographs and transmission electron micrographs of spermatogenesis showing different types of male germ cells. (A-B) spermatogonia (Sg), (C-E) primary spermatocyte (Psc), (F-G) secondary spermatocyte (Ssc). Note: electron dense particle (Ep), endoplasmic reticulum (ER), heterochromatin $(\mathrm{H})$, patch of herterochromatin $(\mathrm{Hc})$, intercellular bridge $(\mathrm{Ib})$, mitochondria $(\mathrm{m})$, nuage $(\mathrm{n})$, somatic sertoli cell (Sec), syntoplasmic complex (Sn). Scale bar A = $25 \mu \mathrm{m} ; \mathrm{C}$ and $\mathrm{F}=20 \mu \mathrm{m}$.
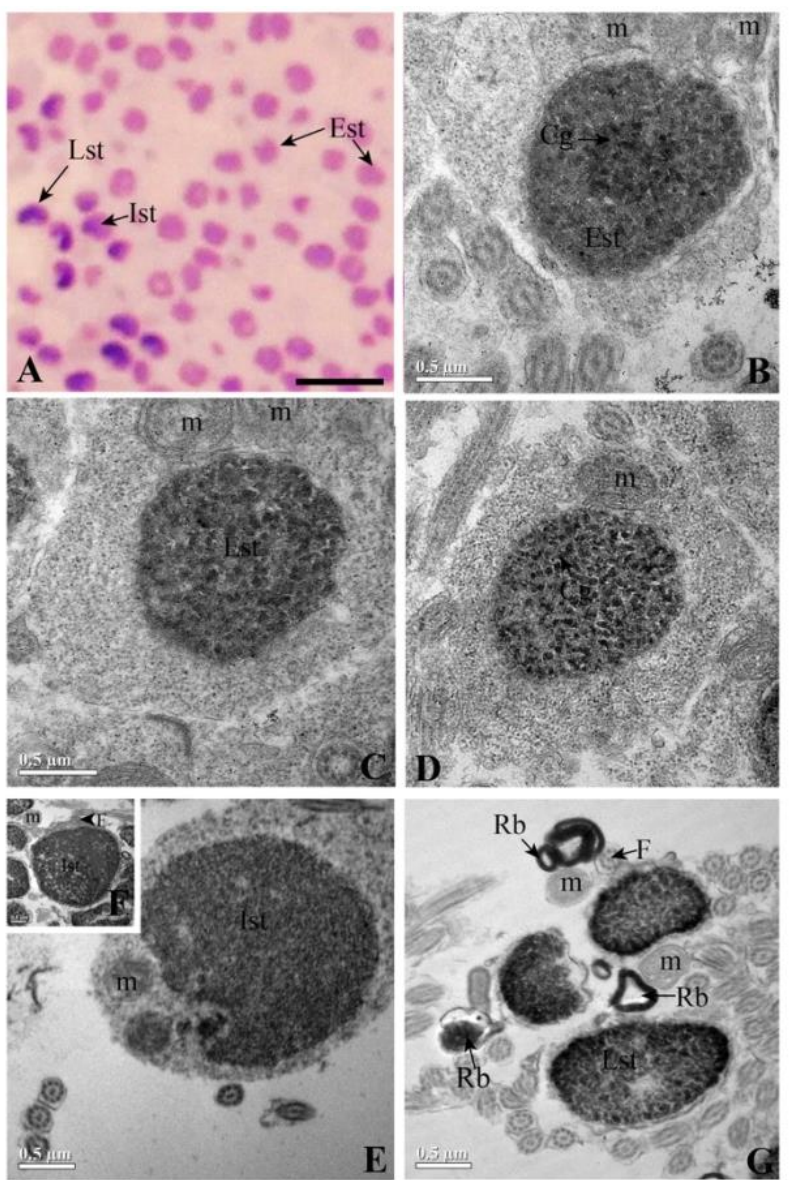

Figure 5. Photomicrograph and transmission electron micrographs showing different stages of spermatids. (A) semithin section of various spermatids, (B-C) early spermatids (Est), (D-F) intermediate spermatids (Ist), $(\mathrm{G})$ late spermatids (Lst). Note: chromatin granule $(\mathrm{Cg})$, flagella $(\mathrm{F})$, mitochondria $(\mathrm{m})$, residual bodies $(\mathrm{Rb})$. Scale bar $\mathrm{A}=25 \mu \mathrm{m}$.

Spermatozoon, the mature spermatozoon had three distinct regions: a head, mid-piece and tail region (flagellum). Based on our observation, the spermatozoon of $R$. brachysoma had characteristics of those belonging to the primitive type, named aquasperm primitive type. If it is considered based on sperm characterization by van der Straten et al. (2006), it will be classified as Type II. The asymmetrical head region appeared as ovoid nucleus, about $2-3 \mu \mathrm{m}$ in length and 3-4 $\mu \mathrm{m}$ in width, due to extreme granular chromatin 
condensation with an acrosome-less head in the anterior region. The short mid-piece was cylindrical of approximately $0.5 \mu \mathrm{m}$. Inserted in the mid-piece, the centriolar complex was present outside the shallow nuclear fossa in bell-shape of ultrathin sections, which was composed of the (i) proximal centriole near the nucleus envelope, and (ii) distal centriole giving rise to the sperm flagellum. This region completely composed of several spherical mitochondria (approximately 0.5-0.7 $\mu \mathrm{m})$ which were irregular cristae and moderately electron-dense. The sperm tail (flagellum), without lateral fins of this species, was estimated about 15-18 $\mu \mathrm{m}$. It mainly consisted of nine triplet's doubles of peripheral microtubules and axonemal doublet of the microtubules. Thus, each axonemal pattern of the flagella has a typical $9+2$ arrangement of microtubules as typically presented in primitive species. A cross section of mid-piece was interconnected by $\mathrm{Y}$-shaped bridge with enclosure by a flagellum plasma membrane and the flagella exhibited no lateral fins (Figures $6 \mathrm{~B}, 6 \mathrm{G}, 7 \mathrm{~A}, 7 \mathrm{G})$.

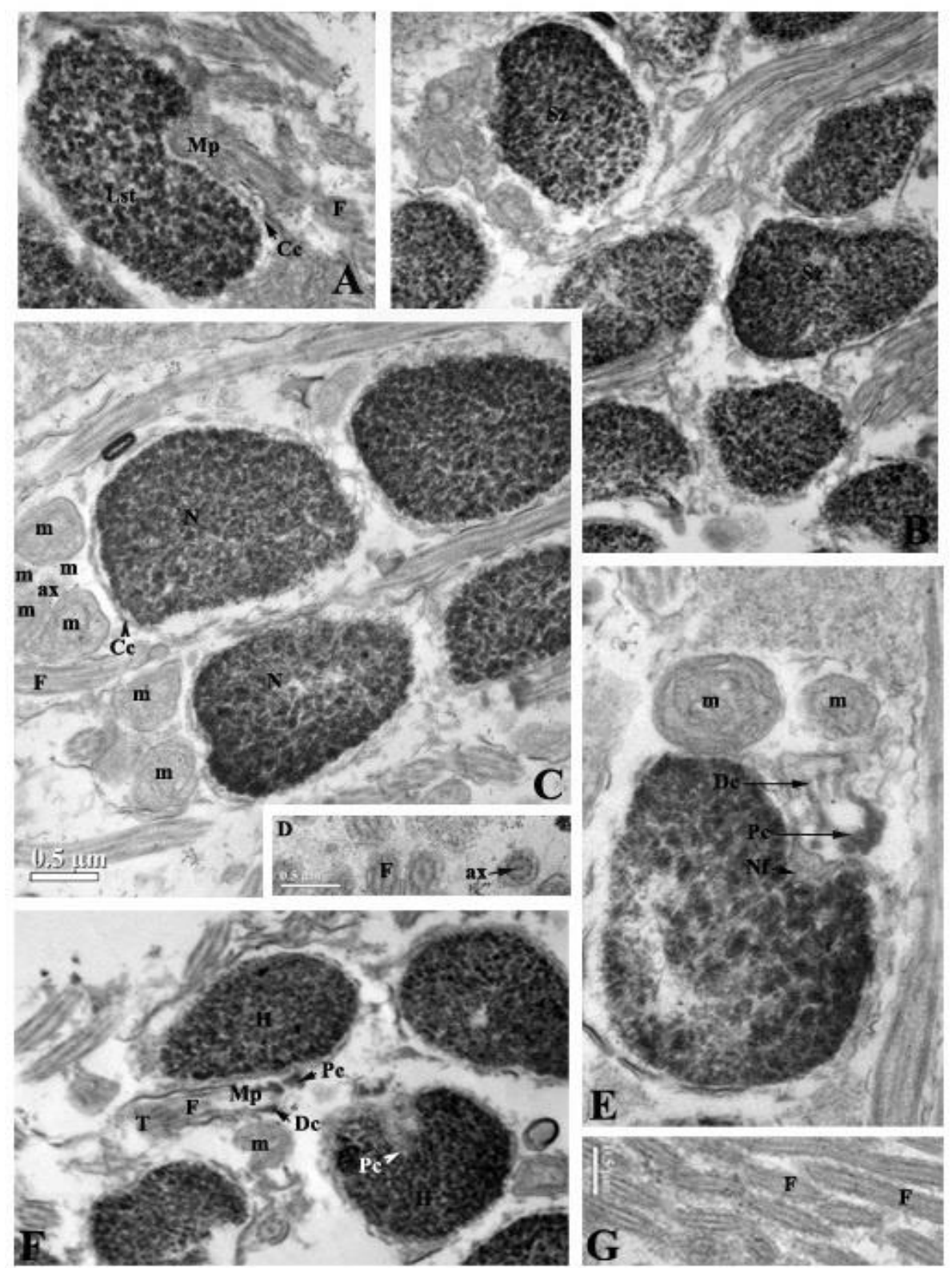

Figure 6. Transmission electron micrographs showing late spermatids (Lst) and spermatozoa (Sz). (A) late spermatids, (B-G) the characterization of spermatozoa. Note: axoneme (ax), cytoplasmic canal (Cc), distal centriole (Dc), flagella $(\mathrm{F})$, head $(\mathrm{H})$, mitochondria $(\mathrm{m})$, mid-piece $(\mathrm{Mp})$, nucleus $(\mathrm{N})$, nuclear fossa $(\mathrm{Nf})$, proximal centriole $(\mathrm{Pc})$, tail $(\mathrm{T})$. 


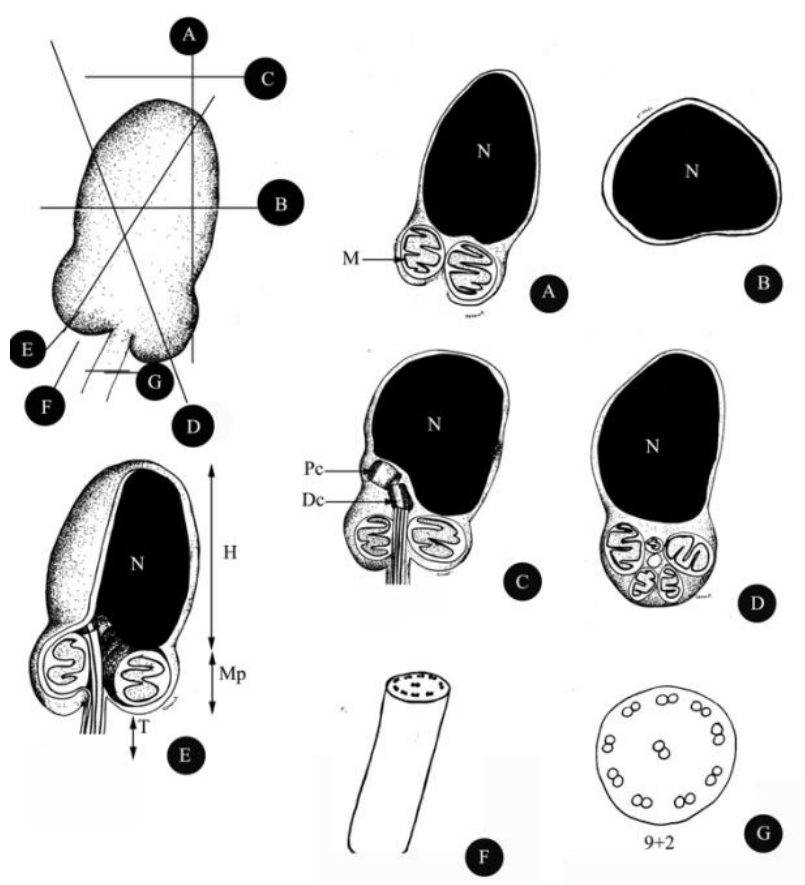

Figure 7. Schematic of several sections showing the characterization of spermatozoa. Note: distal centriole (Dc), head $(\mathrm{H})$, mitochondria $(\mathrm{M})$, midpiece $(\mathrm{Mp})$, nucleus $(\mathrm{N})$, proximal centriole $(\mathrm{Pc})$, tail $(\mathrm{T})$.

During the reproductive season, somatic sertoli cell and perilobular myoid cell were also observed. As to detail, the localization of somatic sertoli cell was exclusively found in the periphery of the lobule and around the spermatogonia. Sertoli cell occurred within the germinal compartment of the spermatogonia. Based on a light microscope study, they were difficult to identify (Figure 5A) but they had a triangular or oval shape with a nucleus which is regular oval with scatting dense heterochromatin under TEM (Figure 8B). Also, the cytoplasm specially contained a few glycogen and several residual bodies which could be classified into two types: laminar bodies and lipofuscin pigments (Figure 8C). Therefore, this characterization underwent active phagocytosis. Several mitochondria and rough endoplasmic reticulum were observed. Each cell was joined by desmosome and tight junctions. Perilobular myoid cells were present near somatic sertoli cell (Figure 8A). Ultrastructurally, they had irregular shape, containing oval or irregular nucleus. The cytoplasm of this cell was mainly filled with high concentration of contractile filaments.
Mitochondria and caveolae-like vesicles were commonly found in this cell (Figure 8D). Each cell was joined by hemidesmosome junctions.

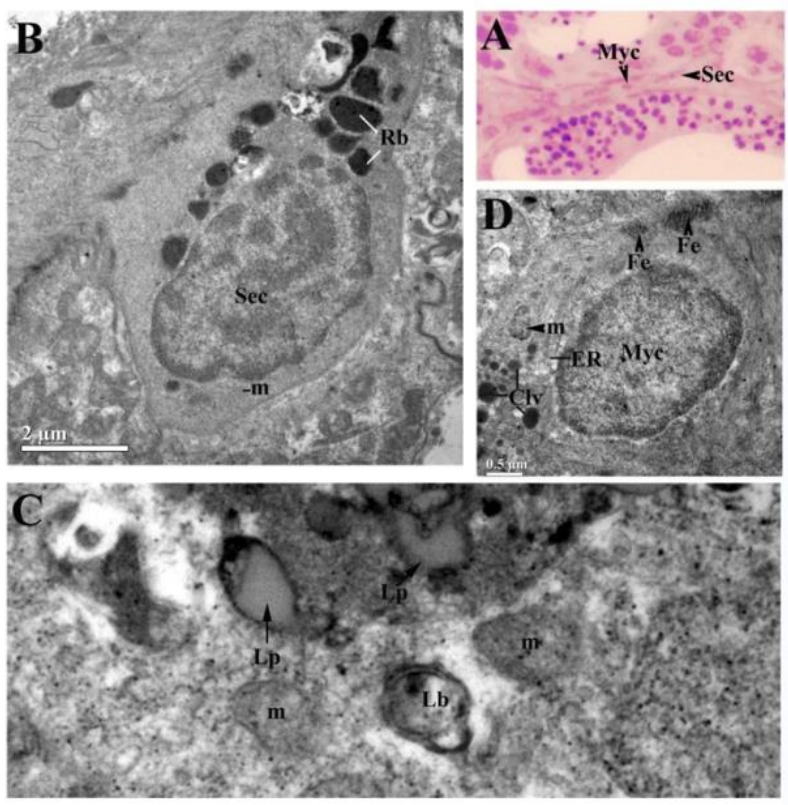

Figure 8. Photomicrograph and transmission electron micrographs showing somatic sertoli cell (Sec) and perilobular myoid cell (Myc). (A) semithin section of somatic sertoli cell and perilobular myoid cell, (B-C) the characterization of somatic sertoli cell containing various types of residual bodies ( $\mathrm{Rb})$, laminar bodies (Lb), lipofuscin pigments (Lp), (D) the characterization of perilobular myoid cell containing caveolae-like vesicles $(\mathrm{Clv})$, endoplastic reticulum (ER), filaments $(\mathrm{Fe})$, mitochondria $(\mathrm{m})$.

\section{DISCUSSION}

Histology and histochemistry of testicular tissue. The testicular parenchyma consists of two parts, the germinal and interstitial compartments. The lobular testis in germinal compartment was the first reported in R. brachysoma in this study, quite similarly to Scombridae group such as Thynnus thynnus (Abascal et al., 2004), Scomber japonicas (Nyuji et al., 2012) and Rachycentron canadum (Brown-Peterson et al., 2002). The testicular structure of this fish was also classified as an unrestricted spermatogonial type due to the presence of spermatogonia along the germinal compartment. It has been commonly observed in most teleost fish, except in the atherinomorphs 
(Grier et al., 1980; Grier, 1993; Parenti and Grier, 2004; Dietrich and Krieger, 2009). The detection of polysaccharides with PAS reaction in the interstitial compartment was presented in the $R$. brachysoma. It was suggested that they concerned the synthesis and secretion of sugars and proteins. Moreover, two main cell types were seen within the interstitial compartment, both perilobular myoid cell and steroidogenic Leydig cells. The perilobular myoid cells were also found similar to those of teleost fish (Billard, 1970; Grier et al., 1989). Its functions concerned the contractile of the sperm in the environment during spawning within seminiferous lobules (Billard, 1970; Grier et al., 1989). The steroidogenic Leydig cells were also mainly presented as cluster cells (about 4-5 cells) near blood vessels, as in other teleost fishes (Billard, 1983; Nagahama, 1983; U.S. EPA, 2006; Dietrich and Krieger, 2009). Its function has been reported in teleost fishes, including Synbranchus senegalensis, Padogobius martensi (Cinquetti and Dramis, 2003) and S. marmotatus (Lo Nostro et al., 2004), which were investigated by histochemical analysis. All these studies were strongly positive to $3 \beta$ hydroxysteroid dehydrogenase and were confirmed to produce the androgens inside the testis.

In the germinal compartments, this part was composed of various seminiferous lobules including somatic sertoli cells and spermatogenesis, in agreement with previous reports (Nagahama, 1983; Billard, 1992; Dietrich and Krieger, 2009). Additionally, seminiferous lobules of R. brachysoma also showed PAS positive, indicating that the secreting fluid may be composed of neutral glycoproteins, acid glycoconjugates, acid carboxylate and sialomucins (Santos et al., 2010). The cytoplasmic processes of the somatic sertoli cells surrounded each spermatocyst as a cyst-liked structure, containing many different stages of spermatogenesis (Nagahama, 1983; Billard, 1992; Dietrich and Krieger, 2009) as in R. brachysoma. As to the functions of somatic sertoli cells, they concerned with metabolites transport (Grier, 1975; Billard et al., 1982) and phagocytosis of residual bodies and degenerating germ cells, including residual sperms (Grier, 1993; Grier and Taylor, 1998), although the characterizations of spermatogenesis like the spermatogenic stages (except for primary spermatogonium and spermatozoa) were present within spermatocysts. The present result differed from García-López et al. (2005), who reported that only primary and secondary spermatogonia were present in the spermatocysts. At the final stage, spermatozoa were centrally located in the seminiferous lobules before they were released into environment, similar to that described in Thunnus obesus (Hashimoto et al., 2003). This stage started the beginning of the fertilization.

\section{Ultrastructure of spermatogenic stages.}

Ultrastructural features of spermatogenic stages are interestingly seen in teleost fish (Fishelson et al., 1990; Quagio-Grassiotto and Oliveira, 2008). Initially, the characterization of spermatogonium of this fish was large cell. Dense osmiophilic material or nuage was also normally occurred at this stage and scattered throughout the cytoplasm, as reported in different species of fishes such as Poecilia reticulata (Billard, 1984), Oryzias latipe (Hamaguchi, 1993) and T. thynnus (Abascal et al., 2004). However, nuage structure in this species was the smallest structure and it could be the first found in primary spermatocyte, which was unclear throughout this research. It was possible that ultrasection (approximately $90 \mathrm{~nm}$ ) in this study was still too thick, resulting in the loss of the details of spermatogonia stage. This particular feature involving origin and function are associated with the synthetic activity of spermatogenic step due to composing the ribonucleoproteins and mRNA (Hamaguchi, 1993; Lo Nostro et al., 2003). After mitosis, the spermatogonia successively became primary spermatocytes. The characterization of the $R$. brachysoma primary spermatocytes was similar to other teleost fishes (Bhatti and Al-Daham, 1978; Brusle, 1981). The nucleus of primary spermatocyte contained high dense chromatin (compared to spermatogonia) and the synaptomemal complexes, particularly pachytene phase. This structure was basically presented in Piaractus mesopotamicus (Romagosa, 1991) and T. thynnus (Abascal et al., 2004). On the other hand, secondary spermatocytes in $\mathrm{R}$. brachysoma were rarely observed. This was similar to those found in several teleost fishes, probably due to their short-term appearance under rapidly dividing (Grier, 1976; Bhatti and Al-Daham, 1978; Brusle, 1981; Burke and Leatherland, 1984). Another 
intercellular bridge, referred to as the cytoplasmic bridge was normally observed connecting during spermatogenic stage (Billard, 1984; Selman and Wallace, 1986). Their bridges were found through spermatocytes to spermatids in this fish.

During spermiogenesis, spermatids were differently seen under chromatin condensation and cytoplasmic organelles changes (Lahnsteiner and Patzner, 1990; Gwo et al., 1993). The developmental pattern of spermatid in this fish could be prominently classified into three morphological stages; early, intermediate (referred to middle) and late spermatids, following the modified criterion from other family fish (Lahnsteiner and Patzner, 1990; Manni and Rasotto, 1997; Quagio-Grassiotto and Oliveira, 2008). At the beginning of spermiogenesis, the early spermatid of this fish was characterized to condense as granular-chromatin mass and the nucleus was completely condensed in the late spermatid. These features have been documented in teleost fish (Todd, 1976; Brusle, 1981; Sprando and Russell, 1988; Gwo et al., 1993).

Finally, the pattern of spermatozoa morphology could be distinctly classified into two types based on the external and internal mode of the fertilization of the fishes (Jamieson and Grier, 1993; Jamieson, 2011). The spermatozoa ultrastructure of $R$. brachysoma had characteristic of that belonging to the primitive type, named aquasperm primitive type, which referred to as external fertilization, according to descriptions by Jamieson (2011), similar to Makaira indica (van der Straten et al., 2006) and T. thynnus (Abacal et al., 2002). It differed from internal fertilization type which had elongated head and complicated midpiece structure (Lahnsteiner and Patzner, 1990). So, the type of spermiogenesis was established to type I and II in this present study, similar with the report by van der Straten et al. (2006). In R. brachysoma, the spermatozoon is considered as type II because of the shallowness of the nuclear fossa and nucleus outside the fossa. This type was evolutionarily more advanced than the type I sperm (Jamieson and Leung, 2011). A similar appearance had been described in scrombrid group; Trichiuridae-Trichiurus japonicus (Hara and Okiyama, 1998), Scombridae-S. australasicus and S. japonicus (Hara and Okiyama, 1998), S. japonicas and S. tritor (Mattei, 1991) and E. alletteratus and T. thynnus (Abascal et al., 2002). Other sperm characterizations of $R$. brachysoma included the asymmetrical morphology of the head appeared as an ovoid nucleus with an acrosome-less in the anterior region, very similar to several scombrid species (Mattei, 1991; Hara and Okiyama, 1998) such as T. thynnus (Abascal et al., 2002). It was well understood that its acrosome-less head was correlated with an egg micropyle (Romagosa et al., 1999; Chung, 2008). Short mid-pieces were presented with several spherical mitochondria. This result agreed with the study in spermatozoon of S. australasicus (Hara and Okiyama, 1998), Spiraea japonica (Hara and Okiyama, 1998) and T. thynnus (Abascal et al., 2002).

An asymmetric uniflagella was described here, similar to those described in most of the teleost species, S. tritor (Mattei, 1991), E. alletteratus (Abascal et al., 2002), S. australasicus (Hara and Okiyama, 1998) and S. japonicas (Mattei, 1991; Hara and Okiyama, 1998). On the other hand, biflagella was only found in few teleosts, such as Ictalurus punctatus (Poirier and Nicholson, 1982), Malapterurus sp. (Mattei, 1988) and Pimelodidae rhamdiasapo (Jamieson, 2011). The flagellum of this species consisted of nine triplet's doubles of peripheral microtubules and the two central singlet microtubules. Thus, each axonemal pattern of the flagella in this fish was a typical $9+2$ arrangement of microtubules as typically presented in primitive species (Romagosa, 1991).

Generally, the function of somatic sertoli cell concerned the nutrition, phagocytosis and steroidogenesis (Gresik et al., 1973). The ultrastructure of sertoli cell was changed during the reproductive season, possibly that the materials within cytoplasm were correlated with reproductive function. A few glycogen particles were found, as in Boleophthalmus pectinirostris, in which these particles were concerned with spermatid nutrition during spermiogenesis (Chung, 2008). However, the study about nutrient during spermatids is unclear. Moreover, somatic sertoli cells in some fish displayed ultrastructural feature, where the change is related to gametogenic cycle (Cinquetti and Dramis, 2003). Testicular tissue was distinctly observed during regression as well as spermiation. Therefore, residual bodies normally observed, indicated the phagocytic function. This was also reported in several teleost (Grier et al., 1980) as well as in mammals (Fawcett, 1975). Perilobular myoid 
cells, which its function concerned the synthesis of the basement membrane (Skinner, 1991), did not degenerate during season. This is also found in many studies (Cinquetti, 1994; Cinquetti and Dramis, 2003). Moreover, contractile network could facilitate the ejection of sperm from the lobules during spawning (Grier et al., 1980) because it exclusively contained the filamentous microfilament. This information was similar to our observations. Therefore, the basis of fine structure of perilobular myoid cell in this fish is directly correlated with its spermiation.

\section{CONCLUSION}

This study analyzed the histological and histochemical characteristics of the gonadal tissue in R. brachysoma, a commercially important marine fish in Thailand. The present result is considered the first report on the spermatogenic stage under light and electron microscopic levels from Thailand. It is also an important information for the phylogeny and systematics, which will be applied or used for the development of aquaculture technology.

\section{ACKNOWLEDGEMENT}

This research was supported by The $100^{\text {th }}$ Anniversary Chulalongkorn University Fund for Doctoral Scholarship. The authors wish to thank Assist. Prof. Dr. Pisit Poolprasert, Dr. Watiporn Yenchum, and Dr. Niwat Kangwanrangsan for their suggestions and comments. We also wish to thank the members of the Aquatic Toxicology Unit, Department of Pathobiology, Faculty of Science, Mahidol University and Fish Biology and Aquatic Health Assessment Laboratory, Department of Marine Science, Faculty of Science, Chulalongkorn University for their support throughout this study. We also specially thank Dr. David V. Furman for critically reading this manuscript.

\section{REFERENCES}

Abascal, F. J., Medina, A., Megina, C. and Calzada, A. 2002. Ultrastructure of Thunnus thynnus and Euthynnus alletteratus spermatozoa. Journal of Fish Biology 60: 147-153.

Abascal, F. J., Megina, C. and Medina, A. 2004. Testicular development in migrant and spawning bluefin tuna (Thunnus thynnus (L.)) from the eastern Atlantic and Mediterranean. Fishery Bulletin 102: 407-417.

Bancroft, J. D. and Gamble, M. 2002. Theory and Practice of Histological Techniques. London: Churchill Livingstone.

Bhatti, M. N. and Al-Daham, N. K. 1978. Annual cyclical changes in the testicular activity of a freshwater teleost, Barbus luteus (Heckel) from Shatt-Al-Arab, Iraq. Journal of Fish Biology 13: 321-326.

Billard, R. 1970. Ultrastructure comparée de spermatozoides de quelques poissons Téléostéens. In Comparative Spermatology, B. Baccetti (ed.) pp. 71-79. New York: Academic Press.

Billard, R. 1983. A quantitative analysis of spermatogenesis in the trout, Salmo trutta fario. Cell and Tissue Research 230: 495-502.

Billard, R. 1984. Ultrastructural changes in the spermatogonia and spermatocytes of Poecilia reticulata during spermatogenesis. Cell and Tissue Research 237: 219-226.

Billard, R. 1992. Reproduction in rainbow trout: sex differentiation, dynamics of gametogenesis, biology and preservation of gametes. Aquaculture 100: 263-298.

Billard, R., Richard, M. and Rombauts, R. 1982. Inhibition of spermatogenesis and vitellogenin in rainbow trout by hormonal additives in the diet. The Progressive Fish-Culturist 44: 15-18.

Brown-Peterson, N. J., Grier, H. J. and Overstreet, R. M. 2002. Annual changes in germinal epithelium determine male reproductive classes of the cobia. Journal of Fish Biology 60: 178-202.

Brusle, S. 1981. Ultrastructure of spermiogenesis in Liza aurata Risso, 1810 (Teleostei, Mugilidae). Cell and Tissue Research 217: 415-424

Burke, M. G. and Leatherland, J. F. 1984. Seasonal changes in testicular histology of brown bullheads, Ictalurus nebulosus Lesueur. Canadian Journal of Zoology 62: 1185-1194.

Chung, E. Y. 2008 Ultrastructure of germ cells, the Leydig cells, and sertoli cells during spermatogenesis in Boleophthalmus pectinirostris (Teleostei, Perciformes, Gobiidae). Tissue and Cell 40: 195-205

Cinquetti, R. 1994. Localization of steroidogenesis in the testis of Padogobius martensi (Pisces, Gobiidae): Histological, histochemical and ultrastructural investigation. Italian Journal of Zoology 61: 309-315.

Cinquetti, R. and Dramis, L. 2003. Histological, histochemical, enzyme histochemical and ultrastructural investigations of the testis of Padogobius martensi between annual breeding seasons. Journal of Fish Biology 63: 1402-1428.

Culling, C. F. A. 1963. Handbook of Histopathological Technique, 2nd. London: Butterworth.

Dietrich, D. R. and Krieger, H. O. 2009. Histological Analysis of Endocrine Disruptive Effects in Small Laboratory Fish. New Jersey: John Wiley \& Sons.

Fawcett, D. W. 1975. Ultrastructure and function of the sertoli cell. In Handbook of Physiology and Endocrinology: Male reproductive system, D. W. Hamilton and R. O. Greep (eds.), pp 21-55. Baltimore: Williams \& Wilkins. 
Fishelson, L., Gibson, R. N. and Delarea, Y. 1990. Unusual cell organelles during spermiogenesis in two species of gobies (Gobiidae, Teleostei). Cell Tissue and Research 262: 397-400.

García-López, Á., Martínez-Rodríguez, G. and Sarasquete, C. 2005. Male reproductive system in enegalese sole Solea senegalensis (Kaup): Anatomy, histology and histochemistry. Histology and Histopathology 20: 1179-1189.

Gresik, E. W., Quirk, J. Q. and Hamilton, J. B. 1973. A fine structural and histochemical study of the Leydig cell in the testis of the teleost, Oryzias latipes (Cyprinidontiformes). General and Comparative Endocrinology 20: 86-98.

Grier, H. J. 1975. Aspects of germinal cyst and sperm development in Poecilia latipinna (Teleostei: Poeciliidae). Journal of Morphology 146: 229-250.

Grier, H. J. 1976. Sperm development in the teleost Oryzias latipes. Cell Tissue and Research 168: 419-431.

Grier, H. J. 1993. Comparative organization of sertoli cells including the sertoli cell barrier. In The Sertoli cell, L. D. Russel and M. D. Griswold (eds.), pp 704-739. Clearwater (Florida): Cache River Press.

Grier, H. J., Linton, J. R., Leatherland, J. F. and de Vlaming, V. L. 1980. Structural evidence for two different testicular types in teleost fishes. American Journal of Anatomy 159: 331-345

Grier, H. J., van den Hurk, R. and Billard, R. 1989. Cytological identification of cell types in the testis of Esox lucius and $E$. niger. Cell and Tissue Research 257: 491-496.

Grier, H. J. and Taylor, R. G. 1998. Testicular maturation and regression in the common snook. Journal of Fish Biology 53: 521-542.

Gwo, J. C., Gwo, H. H. and Chang, S. L. 1993 Ultrastructure of the spermatozoon of the teleost fish Acanthopagrus schlegeli (Perciformes, Sparidae). Journal of Morphology 216: 29-33.

Hamaguchi, S. 1993. Alterations in the morphology of nuages in spermatogonia of the fish, Oryzias latipes, treated with puromycin or actinomycin. Reproduction Nutrition Development 33: 137-141.

Hara, M. and Okiyama, M. 1998. An ultrastructural review of the spermatozoa of Japanese fish. Bulletin of the Ocean Research Institute, University of Tokyo No. 33: 152.

Hashimoto, S., Kurihara, R., Strussmann, A. C., Yamasaki, T., Soyano, K., Hara, A. and Shiraishi, H. 2003. Gonadal histology and serum vitellogenin levels of bigeye tuna Thunnus obesus from the Northern Pacific Ocean - absence of endocrine disruption bio-indicators. Marine Pollution Bulletin 46: 459-465.

Jamieson, B. G. M. 2011. Fish Evolution and Systematics: Evidence from Spermatozoa. Cambridge: Cambridge University Press.

Jamieson, B. G. M. and Grier, H. J. 1993. Influences of phylogenetic position and fertilization biology on spermatozoal ultrastructure exemplified by exocoetoid and poeciliid fish. Hydrobiologia 271: 11-25.

Jamieson, B. G. M. and Leung, L. K. P. 2011. Introduction to fish spermatozoa: The significance of the micropyle in fertilization. In Fish Evolution and Systematics: Evidence from Spermatozoa, B.G.M. Jamieson (ed.), pp 56-72. Cambridge; Cambridge University Press.

Lahnsteiner, F. and Patzner, R. A. 1990. The spermatic duct of blenniid fish (Teleostei, Blenniidae): Fine structure, histochemistry and function. Zoomorphology 110: 63-73.

Lo Nostro, F. L., Grier, H., Meijide, F. J. and Guerrero, G. A. 2003 Ultrastructure of the testis in Synbranchus marmoratus (Teleostei, Synbranchidae): the germinal compartment. Tissue and Cell 35: 121-132.

Lo Nostro, F. L., Antonellin, F. N., Quagio-Grassiotto, I. and Guerrero, G. A. 2004. Testicular interstitial cells, and steroidogenic detection in the protogynous fish, Synbranchus marmoratus (Teleostei, Synbranchidae). Tissue and Cell 36: 221-231.

Manni, L. and Rasotto, M. B. 1997. Ultrastructure and histochemistry of the testicular efferent duct system and spermiogenesis in Opistognathus whitehurstii (Teleostei, Trachinoidei). Zoomorphology 117: 93-102.

Mattei, X. 1988. The flagellar apparatus of spermatozoa in fish. Ultrastructure and evolution. Biology of the Cell 63: 151-158.

Mattei, X. 1991 Spermatozoon ultrastructure and its systematic implications in fishes. Canadian Journal of Zoology 69: 30383055.

Nagahama, Y. 1983. The functional morphology of teleost gonads. In Fish Physiology Vol. 9A, W. S. Hoar, D. J. Randall and E. M. Donaldson (eds.), pp 223-275. New York: Academic Peal.

Nyuji, M., Selvaraj, S., Kitano, H., Shiraishi, T., Yamaguchi, A., Shimizu, A. and Matsuyama, M. 2012. Immunoreactivity of gonadotrophs (FSH and LH Cells) and gonadotropin subunit gene expression in the male chub mackerel Scomber japonicus pituitary during the reproductive cycle. Zoological Science 29: 623-629.

Parenti L. R. and Grier, H. J. 2004. Evolution and phylogeny of gonad morphology in bony fishes. Integrative and Comparative Biology 44: 333-348.

Poirier, G. R. and Nicholson, N. 1982. Fine structure of the testicular spermatozoa from the channel catfish, Ictalurus punctatus. Journal of Ultrastructure Research 80: 104-110.

Puchtler, H. and Waldrop, F. W. 1978. Silver impregnation methods for reticulum fibers and reticulin: A reinvestigation of their origins and specificity. Histochemistry 57: 177-187.

Quagio-Grassiotto, I. and Oliveira, C. 2008 Sperm ultrastructure and a new type of spermiogenesis in two species of Pimelodidae, with a comparative review of sperm ultrastructure in Siluriformes (Teleostei: Ostariophysi). Journal of Comparative Zoology 247: 55-66.

Romagosa, E. 1991. Mudanças morfológicas (microscopia de luz e eletrônica) das gônadas de Pacu, Piaractus mesopotamicus (Holmberg, 1887) durante o ciclo reprodutivo, em condições de confinamento, M.Sc. thesis, Universidade Estadual Paulista, UNESP, Rio Claro, SP, Brazil.

Romagosa, E., Narahara, M. Y., Borella, M. I., Parreira, S. F. and Fenerich-Verani, N. 1999. Ultrastructure of the germ cells in the testis of matrix Brycon cephalus (Teleostei, Characidae). Tissue and Cell 31: 540-544.

Santos, J. E., Veloso-Junior, V. C., Andrade Oliveira, D. A. and Hojo, R. E. S. 2010. Morphological characteristics of the testis of the catfish, Pimelodella vittata (Lutken, 1874). Journal of Applied Ichthyology 26: 942-945.

Selman, K. and Wallace, R. A. 1986. Oogenesis in Fundulus heteroclitus. IV. Yolk-vesicle formation. Journal of Experimental Zoology 239: 277-288.

Senarat, S., Kettretad, J. and Jiraungkoorskul, W. 2016. Neuroanatomy and histology of the central nervous system in short mackerel, Rastrelliger brachysoma (Bleeker, 1851) Walailak Journal of Science and Technology. 13: 531-541.

Skinner, M. K. 1991. Cell-cell interactions in the testis. Endocrine Reviews 12: 45-77.

Sprando, R. L. and Russell, L. D. 1988. Spermiogenesis in the bluegill (Lepomis macrochirus): A study of cytoplasmic events including cell volume changes and cytoplasmic elimination. Journal of Morphology 198: 165-177.

van der Straten, K. M., Collette, B. B., Leung, L. K. P. and Johnston, S. D. 2006. Sperm morphology of the black marlin (Makaira indica) differs from Scombroid sperm. Bulletin of Marine Science 79: 839-845. 
Todd, P. R. 1976. Ultrastructure of the spermatozoa and spermiogenesis in New Zealand freshwater eels (Anguillidae). Cell and Tissue Researcb 171: 221-232.

Vidal, B. C. 1988. Histochemical and anisotropical properties characteristics of silver impregnation: The differentiation of reticulin fibers from the other interstitial collagens. Zoology Jb Anatomy 117:485-494.

United States Environmental Protection Agency (US EPA). 2006. Histopathology guidelines for the Fathead Minnow
(Pimephales promelas) 21-day reproduction assay. Available on:

http://www.epa.gov/endo/pubs/atth_histopathologyguid elines_fhm.pdf [accessed on 9 May 2015]

Wilson, J. M., Bunte, R. M. and Carty, A. J. 2009. Evaluation of rapid cooling and tricaine methanesulfonate (MS222) as methods of euthanasia in zebrafish (Danio rerio). American Association for Laboratory Animal Science 48: 785-789. 